\title{
Identifying Endogenous and Exogenous Indicators to Measure Eco-Innovation within Clusters
}

\author{
Nohora Mercado-Caruso ${ }^{1,2, *}$, Marival Segarra-Oña ${ }^{1}\left(\mathbb{D}\right.$, David Ovallos-Gazabon $^{3}(\mathbb{D}$ and \\ Angel Peiró-Signes ${ }^{1}$ (i) \\ 1 Department of Management, Universitat Politécnica de Valencia, Spain, 46022 Valencia, Spain; \\ maseo@omp.upv.es (M.S.-O.); anpeisig@omp.upv.es (A.P.-S.) \\ 2 Departamento de Productividad e Innovación, Universidad de la Costa CUC, Barranquilla 080001, Colombia \\ 3 MacondoLab, Universidad Simón Bolívar, Barranquilla 080001, Colombia; \\ david.ovallos@unisimonbolivar.edu.co \\ * Correspondence: nmercado1@cuc.edu.co; Tel.: +57-3156514613
}

Received: 26 May 2020; Accepted: 17 July 2020; Published: 29 July 2020

check for updates

\begin{abstract}
Scientific and business environment literature shows that green, sustainable innovation or eco-innovation has proven to be a source of competitive advantage today. The industrial clusters, their dynamism, and the synergies created within them attract a lot of attention from the scientific community. However, to date, the joint study of these two concepts and, more specifically, the factors that drive eco-innovation specifically in a cluster, have not been studied in depth. This article models eco-innovation in industrial clusters, thus addressing this gap and proposing a model based on information gathered from the literature and a detailed analysis of behavior in relation to eco-innovation in different sectors. Results suggest that including eco-innovation variables and measures may have positive implications such as improvements at the strategic level and the reduction of costs and use of resources. An eco-innovation model for clusters is proposed. It considers eight key factors that seek to raise its competitive level by promoting eco-innovation within clusters. The model includes five internal factors that analyze business capabilities and three external factors that study the effect of launching eco-innovative activities. This model could help the companies' managers and those responsible for clusters in creating more successful strategies to increase competitiveness by enhancing eco-innovation. It could also serve as a guide for government entities in the performance of eco-innovative activities in economic sectors.
\end{abstract}

Keywords: cluster; competitiveness; eco-innovation; innovation; business performance

\section{Introduction}

The concept of eco-innovation is linked to the relationship between competitiveness and care for the environment [1]. For the Organization for Economic Cooperation and Development [2], eco-innovation arises not only from concern for the environment, but also from the implementation of new strategies within an organization, which creates benefits such as increased productivity, competitiveness, reduced costs, and access to new markets [3]. The concept of eco-innovation discussed in this article is related to the ability of companies to be more competitive by considering the environment as a driver of change in production processes, use of technologies, marketing strategies, internal environmental rules, access to new markets, and the responsibility to support society's environmental awareness [1,4].

On the other hand, among the different advantages of belonging to clusters from which companies can benefit, one of the most important is the competitive advantage obtained due to the vibrant economic interactions among producers, suppliers, competitors, and clients [5]. The close relations 
that are established, as well as the knowledge and information transfer, strengthen innovation, interdisciplinarity, and new government policies to create networks of business cooperation [6,7].

A cluster is a set of companies that are related by their value chain, with companies belonging to different industries but still interrelated. Companies belonging to a cluster are located in the same geographical area. This agglomeration, which generates business networks and increases the efficiency, both individually and as a group, is known as the economy of agglomeration [8,9]. Therefore, not only is a close relationship created with the overall goal of raising competition, but also a high cooperation between the parties, leading to the development of technologies, commercialization derived from research, creation of new areas of demand, and increased capacity as the system becomes adaptive to changes in the external economy; this leads to the success of the cluster due to its high degree of growth and innovation [10-12].

The competitiveness in a cluster generates a shared value and strategic level that is superior to that of a single company; therefore, a collective strategy establishes a win-win of the entities associated to it. Competitive advantage is measured by the profitability of the organizations, and there are different ways of achieving it. One way is through the differentiation of products and services, and also through the reduction of costs and the increase of the profit margin.

Eco-innovation has gained importance on the part of companies, researchers, and governments who formulate economic policies, and for this reason, applying eco-innovation is necessary to create more sustainable societies $[13,14]$. When studying eco-innovation within the cluster, we consider it an extension of innovation that contributes to the environmental growth of different industries. Thus, eco-innovation in clusters appears to potentiate companies' value chains and the swift transition to becoming sustainable societies as well as enhance business competitiveness [15].

The overall objective of the paper is to analyze the factors that drive eco-innovation in clusters. To do so, the existing literature will be reviewed and, based on that, we will present a model that considers all the variables affecting eco-innovation and the aspects to be taken into account. This study will be especially useful for those companies in clusters that have not yet developed eco-innovative activities. It will provide them with a roadmap to follow. Companies that have already started their implementation can potentiate their eco-innovative projects.

The current literature has already identified some studies that establish the determining factors that drive eco-innovation in clusters. A study by Daddi and De Giacomo [15] provides evidence that eco-innovation can strengthen the ability of companies to recover and update their behavior with regard to management and strategic fields to align themselves with the most innovative competitive challenges. It is important to establish effective indicators to measure eco-innovation given its complexity from being applied in more than one sector of the industry [16]. This study analyzes the determining or driving factors of eco-innovation, taking worldwide research as a reference to examine its incidence in clusters. A conceptual model is proposed to study the factors that drive eco-innovation in clusters to create more competitive business strategies and, thus, design effective tools that promote eco-innovation and, as a consequence, create societies that are more committed to environmental sustainability [17-19].

Consequently, the following research question has been developed: What are the main factors that encourage eco-innovation in a cluster?

This research contributes to the literature in different ways. It analyses the importance of eco-innovation in the literature and how it has been applied worldwide in industrial clusters to improve their competitiveness. A cluster is a dynamic entity that benefits from the individual actions of companies and organizations that are part of it, but its orientation towards a greener innovation activity can also be fostered either with public policies or private initiatives. The objective of this paper is to identify which are the key variables that impact the transformation of a cluster to a more eco-innovative entity. Through an exhaustive analysis of the literature, we will propose a model based on internal factors and external factors to explain what drives eco-innovation activities in industrial clusters, identifying the factors that intervene in its dynamics. 


\section{Literature Review}

In the literature on innovation, the inclusion of elements related to sustainability tends to be used as a strategy to improve innovation in products and processes, revolutionize existing markets, and introduce a new approach: Eco-innovation [20]. When introducing the concept of eco-innovation as a result of sustainable innovations, it is necessary for more prosperous and competitive societies to focus on the current and future environmental issues to improve energy and resource consumption [21]. This has a significant positive effect on competitiveness [22]. As clusters are structures that overlay an industry or related industries [23], fostering eco-innovation within a cluster is compatible with the survival of companies belonging to the cluster by reducing environmental damage through more ecological products, eco-processes, novel ideas for products/services, increased cooperation between the clusters actors and, thus, business competitiveness [24].

The tools employed to analyze the degree of eco-innovation on a business level include indicators or factors [25-29], some of which are related to the number of economic benefits for businesses, the level of collective efficiency and the environmental rules implemented. When analyzing the factors that drive eco-innovation, one of the most important factors considered is environmental regulations [30-33]. In Europe, for example, it has been a determining factor for the development of industries that manage natural resources [34]; previously, they were considered an imposition for companies, but the thinking has changed and today they are considered favorable when innovating, since they help companies to identify efficiency failures in their processes and are used as a tool to reduce default and production costs, improving competitiveness [35,36]. The companies discovered that by investing financially in eco-innovation activities, their competitive advantage also increased [37,38], bringing benefits such as cost savings, improved corporate image, marketing advantages, sustainable growth in the environment, and creation of new markets [13,14].

The benefits of eco-innovation should not only be studied from the economic benefits that they can bring to the company, but also from the social benefits that they can provide. For instance, according to Segarra-Oña et al. [39], eco-innovation is considered successful when environmental contributions to society, creation of new jobs, and growth of more sustainable societies are evidenced. It should be noted that to achieve these benefits, changes are needed in the organizational structure of companies, in internal processes and in how companies establish pull-push marketing strategies. It is here where concepts such as eco-design and changes in relationships with suppliers, customers, and distributors emerge, and where environmental awareness integrates new activities in the value chain $[40,41]$.

Once the literature was reviewed, different indicators for the measurement of eco-innovation were analyzed, the study by Kemp and Horbach [25] performed a review on how to measure eco-innovation in companies through surveys, the number of patents, and access to documentary sources. Survey analysis has been the most widespread and widely used due to its easy application. Arundel and Kemp [42] proposed a series of indicators grouped by input indicators and intermediate indicators that are based on the measures implemented by companies and direct and indirect output indicators based on the benefits achieved. Cheng and Shiu [40] applied the input-output approach proposed in Arundel and Kemp's [42] work and grouped their indicators according to the implementation of eco-innovation: (1) Implementation of eco-processes, (2) implementation of eco-products, (3) innovation strategy, and (4) performance of the company. Another interesting approach to the measurement of eco-innovation is proposed by Scarpellini et al. [35], who developed a methodology to analyze the main characteristics of eco-innovation projects from the perspective of the business strategy, taking into account environmental, economic, and social indicators. Cheng and Shiu [40] also developed a set of indicators for the measurement of eco-innovation projects, grouping them into four dimensions or constructs: Green economy performance, economic and social performance, technological accumulation performance, and environmental protection performance. Likewise, the European Commission (EU) [14] has been interested in establishing indicators for eco-innovative activities that illustrate the performance of innovation in the EU member states. The objective is to 
analyze the performance of the countries and measure their ability to promote an economic, social, and environmental vision according to the evaluated context.

Of the few eco-innovation studies found in specific sectors, Italy's study on industrial businesses [15] shows that businesses that invest in creating differential opportunities, product innovation, technology, and new jobs to manage eco-innovative activities gain economic advantages and efficiency in the sector's production processes. Similarly, a study by Hojnik and Ruzzier [38] involving 223 Slovenian businesses concludes that businesses that make adjustments to strategic objectives using eco-innovative initiatives obtain higher profitability, positive sustainable image, growth, and competitive benefits. Another study involving 3200 Spanish manufacturing businesses [41] states that public regulations and investments in research and development $(R \& D)$ are the triggers to implement eco-innovation activities, while government subsidies and the market are not considered key factors for eco-innovation.

The eco-innovation study carried out in 222 companies in the Spanish construction sector [43] reveals that the companies that invest the most in $R \& D$ are more successful in environmental innovations than those that do not. The study concludes that eco-orientation when innovating does not depend on the descriptive variables of the company (size, number of employees, etc.) but on its initiatives and behaviors. By studying the conditions that drive the eco-innovation and its effect on business performance of 442 manufacturing companies in China [44], it was revealed that technological and organizational capabilities and the creation of instruments to measure the degree of eco-innovation contribute to its development. This study shows that eco-innovation improves the environmental performance and economic status of companies, achieving resource efficiency. However, Cai and Li [44], and also Esty and Winston [1], showed that it is not enough to depend on institutional factors, such as environmental regulations or pressure from competition to develop eco-innovation, but also on the internal resources that companies have. This is why it is proposed to improve environmental policies where the internal resources and installed capacities of companies can be improved to carry out these types of activities.

Clusters by their nature have a shared vision of a strategy, resources, efforts, and goals, while remaining competitive in the same market $[45,46]$. Normally, defining the concept of innovation establishes a relationship with technology, but it goes much further, as it relates to business investment, human resource capabilities, $R \& D$, and new knowledge [47-51]. Knowledge transfer is faster within clusters, as well as the creation of strategies based on cooperation [52]. The degree of innovation is subject to the performance of a company, and the more robust it is, the greater the commitment to innovation [53]; the greater number of relationships that may exist in a cluster, the higher the level of innovation. Porter [5] was the first author to state that companies that are connected in the same geographical area have better access to knowledge and its transfer, thus both the size of the companies and their proximity to each other are an advantage. One of the characteristics of clusters is the enhancement of innovation and alliances with competitors to support companies strategically located in a geographical area [7]. For its part, the European Commission [14], as a strategy to improve the competitiveness of medium and small companies, has created an innovation cluster policy, so that clusters with sufficient critical mass and innovative potential could improve their cooperation strategies and be able to access the internationalization of the company.

As the innovative cluster concept evolves and the eco-innovative cluster concept is introduced, a new cycle of economic development is promoted in a region which naturally induces a new cycle of attraction of companies with environmental technologies. Likewise, aspects of social welfare will be incorporated, increasing eco-competitiveness as a pillar of the economy of a region.

De Gouvea and Kassicieh [54] analyzed the process of creating a water cluster for the Amazon region of Brazil. It ensures that by incorporating eco-innovation activities in the cluster and joint work between companies, government entities, industrial parks, and institutions, such as research centers, the region's competitive advantage was increased by incorporating an eco-innovation economy based on water. Cai and $\mathrm{Li}$ [44] confirmed that clusters are an important part of eco-innovation and proposed 
to further study the resources that companies require to develop eco-innovative skills since it will affect the amount of new innovations. A successful case of an eco-innovative cluster is the ecological cluster of Wallonia in Belgium [55]. It brings together more than 150 companies and other institutions for the development of eco-innovative projects for sustainable construction, resource management, and material recovery and subsequent reuse [55]. This cluster, through the focus of the group of companies, has been able to access government funds to carry out research and innovation activities. In agreement, when innovating business models in clusters, it is important to include resource efficiency, circular economy, and cleaner production as aspects proposed by eco-innovation to reduce costs and consequently create companies who make positive environmental commitments [54,56].

Among the initiatives of the Europe 2020 strategy, one of its main objectives is an industrial policy for globalization with efficient economic and environmental processes. Eco-innovative clusters serve to improve the conditions of companies and boost markets and their internationalization more quickly through sustainable policies [57-59]. However, it is important to identify the necessary factors to promote these types of activities, since there are few studies that propose an eco-innovation model that serves to potentiate sustainable economies.

\section{Materials and Methods}

To determine the search parameters, a review of the drivers of eco-innovation was conducted, which lead to a definition developed by Hojnik and Ruzzier [31] that established that factors based on motivation are stimuli of eco-innovation, as in the case of environmental regulations, customer demand, and pressure from the competition.

These drivers are considered a great help to the different types of innovations that may occur, such as product, process, and organizational innovation. The literature also establishes that these drivers are normally conditioned by internal and external factors $[60,61]$.

To design the eco-innovation model in industrial clusters and determine the main factors that motivate cluster eco-innovation, the literature on global eco-innovation studies was evaluated. An exhaustive search was performed in scientific databases, Web of Science and Scopus, that are widely recognized for publication analysis. The search equation employed was as follows:

\section{(eco-innovation) AND ((eco-innovation AND model)) AND ("environmental innovation") AND} (driver eco-innovation)

Information about the mentioned databases was collected for 625 publications, with a cut-off date of 2020. Following this, data cleanup was conducted through the Mendeley ${ }^{\circledR}$ bibliographic reference manager by using the "check for duplicates" tool and eliminating duplicate articles; this yielded 477 articles. Then, a more advanced filter was applied, wherein only the studies containing keywords related to 'determining', 'sustainable innovation', and 'eco-innovative factors' were selected. Finally, 431 articles were eliminated, and 46 specific works on the theme were obtained (see Figure 1).

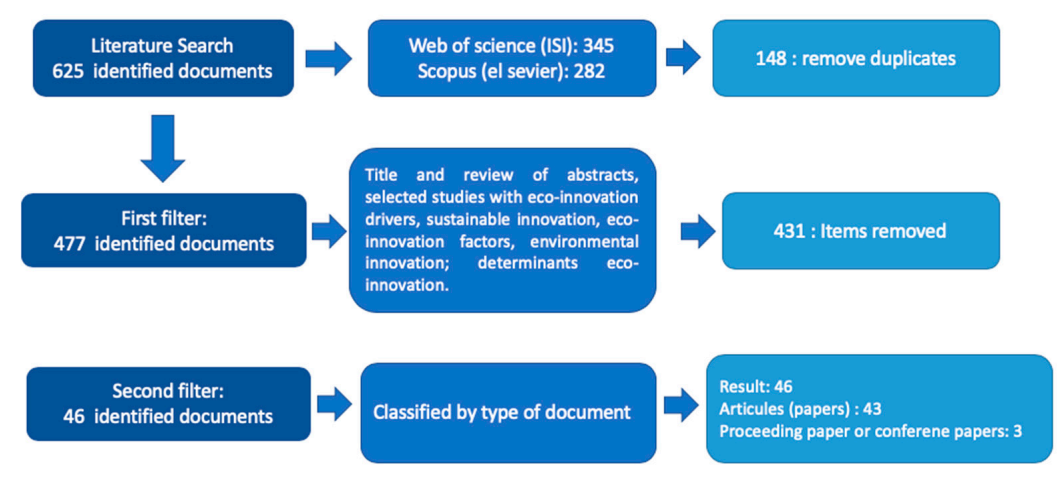

Figure 1. Eco-innovation study selection process. Compiled by author. 
Of the 46 chosen studies, 10 were found to contain detailed studies of eco-innovation in clusters $[15,16,22,62]$. Notably, the other 36 articles do not mention the word 'cluster'; however, they highlight eco-innovation in specific sectors [44,63-65]. As a result, the factors or determinants used worldwide have been analyzed in detail among others, wherein they propose different determinants or factors to measure eco-innovative activities. The data are refined by taking this information into account, analyzing the most important authors and determinants or variables used to measure eco-innovation and the variables that impact eco-innovative activities.

\subsection{Results: Proposed Model Factors}

Kesidou and Demirel [32] indicated that demand factors affect the decision of companies to carry out eco-innovation and do not influence the level of investment in them. It also suggests that companies initiate eco-innovation activities as a measure of customer and society satisfaction. Cruz and Teixeira [10] investigated the correlation between eco-innovation and competitiveness by evaluating the economic performance in the clusters through the indicators of employment, production, export, and critical mass of the cluster. The aim of this study was to analyze how eco-innovation can help companies recover in the long term by improving their strategic behavior and aligning themselves with innovative challenges. Sara and Tiberio [16] studied how companies that continue to seek operational flexibility, production capacity, reduced labor costs, and lower energy consumption are prepared to adopt an environmental orientation, and propose several factors to measure the level of eco-innovation. In the study by López Jiménez et al. [12], the role of the capacity of torsion in the clusters was found to be a fundamental factor for their performance, helping companies to introduce innovation through external knowledge of the cluster networks. However, there are divergences in managers when making strategic decisions due to the imbalances in external and external knowledge management. Other studies $[56,57,66]$ propose eco-innovation models that add circular economy indicators and recommend for their implementation the development of modern technologies that allow the recovery of valuable materials. It is suggested that regional policies should be analyzed to allow for the creation of indicators that are closer to reality. Some of these indicators were included in the instruments proposed for the measurement of eco-innovation $[25,26,35,40,42,58]$.

The analysis performed on the literature highlighted the need for a more thorough study. The proposed model brings together diverse factors that foster eco-innovative activities as identified by the research of world-renowned eco-innovation authors. Several studies on eco-innovation in cluster structures highlight the work of Arranz et al. [67] that fosters cluster creation due to the impact of Small and medium-sized enterprises (SMEs) in activating national economies, for which the European Union created multiple strategies to promote and strengthen the economies of conglomerates to make them competitive on an international scale and gain worldwide visibility, as seen when analyzing cluster experiences in India, Pakistan, Japan, and China [11,68]. Arita [11] stresses the role of the capabilities generated, especially when there is an innovation support system for such initiatives and business growth [69]. Clusters in the creative and cultural industry are highlighted as research trends in this group of works [70]. Many steps are taken by agencies to encourage cluster creation given its advantages. In Latin America, for example, agencies such as the Inter-American Development Bank and the World Bank develop competitiveness programs to support eco-innovation in products, services, and processes of businesses through cluster initiatives and the support of chambers of commerce as regulating organizations [15].

The eco-innovative determinants proposed in this model are segmented into internal and external factors. Internal factors include resources, characteristics, and supplies, commitment of business management to perform eco-innovative activities, businesses reaction to market pressure, and clusters' cooperation networks. Business size and the sector of study were taken as the controlling variables. In this case, the model analyses how the size and sector to which the cluster belongs influence the development of sustainable innovation activities. Figure 2 shows the proposed model for measuring eco-innovation factors in clusters with the associated variables. 


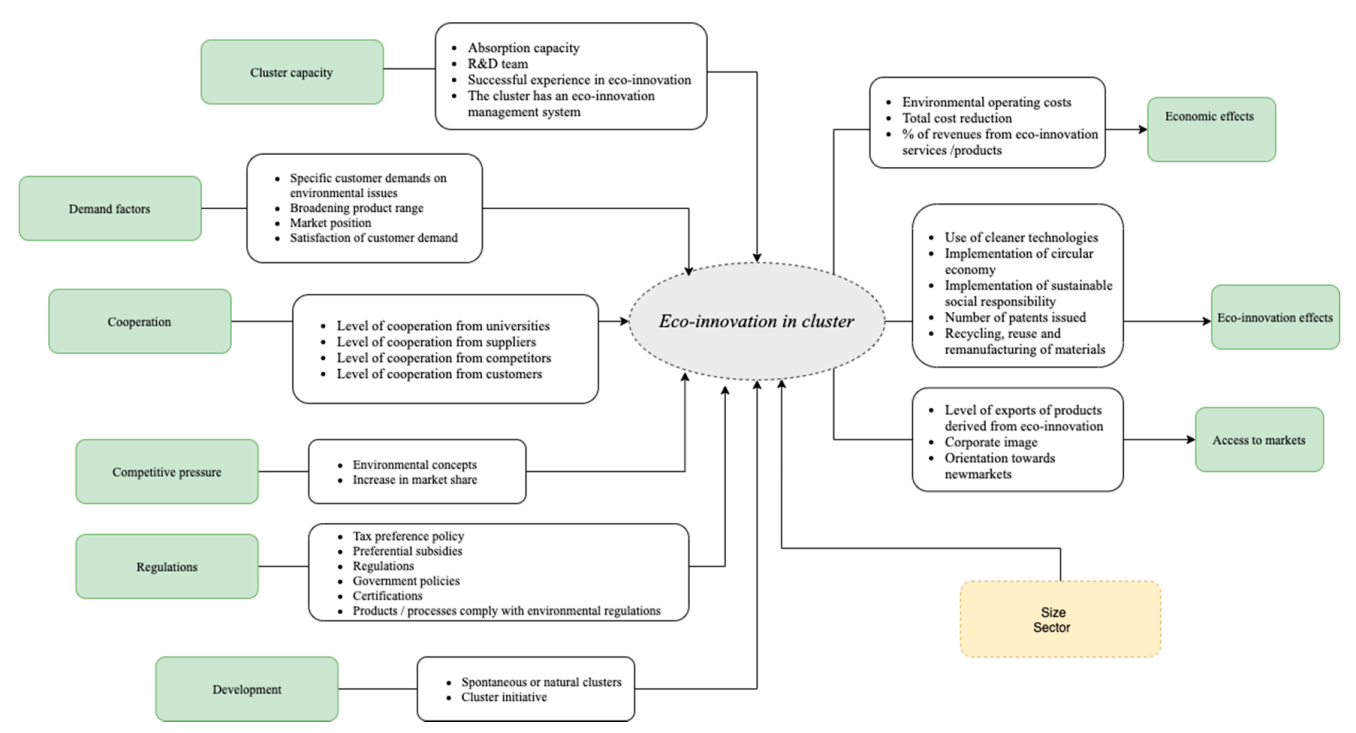

Figure 2. Conceptual model proposed for the measurement of eco-innovation factors in industrial clusters. Factors are identified in green color; analysis variables in white and control variable in yellow. Compiled by author.

The proposed model provides a more specific insight into the drivers of eco-innovation. It brings together a set of factors applied in a cluster or in specific sectors outlined in the literature, creating a broader view of the indicators associated with each of the factors. This new cluster model is expected to be a support for the leaders of the companies and for the actors that coordinate the clusters in a region, as well as a tool to create policies that encourage cluster activities around an environmental era.

The cluster eco-innovation model proposes an instrument to collect information on the cluster you want to study with each of the proposed factors that drive eco-innovation and to measure the incidence of each of the assigned variables to the factors (see Appendix A). The questionnaire was designed to collect information on the factors that drive eco-innovation and to measure the incidence of each of the variables attached to the proposed factors. The questionnaire was measured using various items adapted from Hojnik and Ruzzier [31], from the final report to measure eco-innovation in SMEs proposed and validated by Kemp et al. [25,26], as well as questions taken from the questionnaire of the Economic Commission for America Latina and the Caribbean (ECLAC) [15], from the study of the European cluster observatory by Barsoumian, Severin, and Spek [59], and also from the study developed in Chinese companies on the drivers of eco-innovation [44]. For the questionnaire, multiple element scales were implemented to measure each factor in the model, and a 7-point Likert scale ranging from "strongly disagree" (1) to "strongly agree" (7) was combined for the questionnaire. The questionnaire was structured in this way to analyze by means of the fuzzy sets Qualitative Comparative Analysis (fsQCA) the incidence of the variables of each of the factors in cluster eco-innovation. We selected the FsQCA technique as the following step for this research project because it uses Boolean logic instead of the traditional correlation methods to establish causal conditions strongly related to a particular outcome. Our study is based in a scale that has been used and validated in previous studies, and we will apply a methodology that it has been growing in the recent years. This approach, as we indicated, has not been yet explored and should complement the actual knowledge about the eco-innovation attitude and potential within clusters.

Nine questions were included to characterize the companies consulted. To guarantee the validity of the questionnaire, three experts in industrial clusters from ACOPI (Colombian Association of Micro, Small, and Medium-sized Enterprises) were consulted; they reviewed the initial structure and adaptation of the proposed items. Then, the questionnaire was reviewed by three innovation experts from the Universidad de la Costa -CUC- to improve the validity of the proposed questions (see Appendix A). Table 1 shows Eco-innovation determinants analyzed in literature for this work. 
Table 1. Eco-innovation determinants analyzed in literature.

\begin{tabular}{|c|c|c|c|c|c|c|c|c|c|c|c|c|c|c|c|c|c|c|c|c|}
\hline & 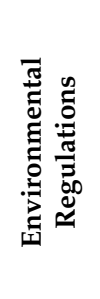 & 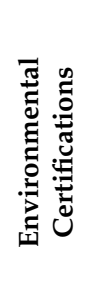 & 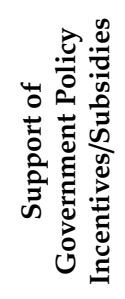 & 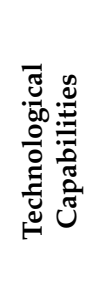 & 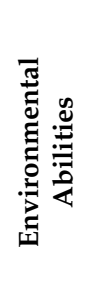 & 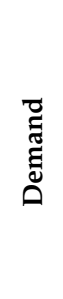 & 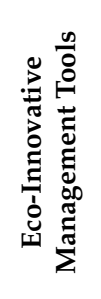 & 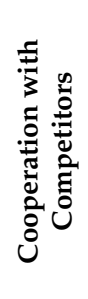 & 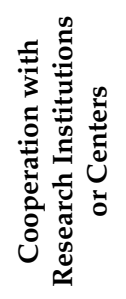 & 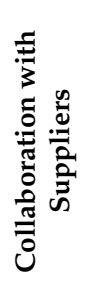 & 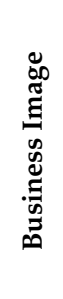 & 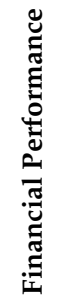 & 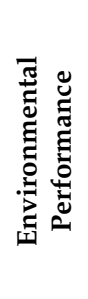 & 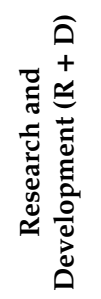 & 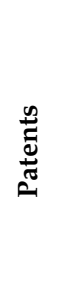 & 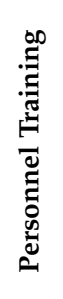 & 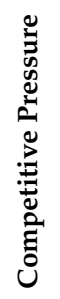 & 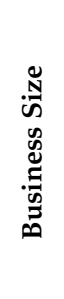 & 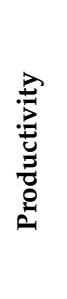 & 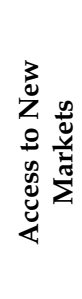 \\
\hline (Kesidou \& Demirel, 2012) [32] & $x$ & & $x$ & $x$ & $x$ & $x$ & & & & & & $x$ & & $x$ & & & & & & \\
\hline (Tessitore et al., 2010) [22] & $x$ & $x$ & & & & & $x$ & & & & & & $x$ & & & & & & & \\
\hline (Diaz \& Montalvo, 2019) [67] & $\mathrm{x}$ & $\mathrm{x}$ & $x$ & & $\mathrm{x}$ & & & $x$ & $x$ & $\mathrm{x}$ & & & $\mathrm{x}$ & & & & & & & \\
\hline (Veugelers, 2012) [71] & $x$ & $x$ & $x$ & & & $x$ & & $x$ & $x$ & $x$ & & & $x$ & $x$ & & & $x$ & & $x$ & \\
\hline $\begin{array}{c}\text { (Segarra-Oña \& Peiró-Signes, } \\
\text { 2014) [66] }\end{array}$ & & & $x$ & $x$ & & & & $x$ & $x$ & & & $x$ & & $x$ & $x$ & $x$ & & $x$ & $x$ & $\mathrm{x}$ \\
\hline (Ghisetti \& Marzucchi, 2014) [72] & $x$ & & $x$ & & & & & $x$ & $x$ & $x$ & & & & $x$ & & $x$ & & & & $x$ \\
\hline $\begin{array}{l}\text { (Borghesi, Cainelli \& Mazzanti, } \\
\text { 2015) [73] }\end{array}$ & $x$ & & $x$ & $x$ & & $x$ & & & & & & & & $x$ & & $x$ & & $x$ & $x$ & $x$ \\
\hline (Smol \& Kulczycka, 2017) [57] & $x$ & $x$ & & & & & & & & & & & $x$ & $x$ & $x$ & $x$ & & & $x$ & $x$ \\
\hline (Hojnik \& Ruzzier, 2016) [31] & & & $x$ & & & $x$ & $x$ & & & & & & & & & & $x$ & & & \\
\hline (Sáez-Martínez, et al., 2016) [49] & & & $x$ & $x$ & & $x$ & & $x$ & $x$ & $x$ & & & & $x$ & $x$ & & & & $x$ & \\
\hline (Del Rio et al., 2017) [74] & $x$ & $x$ & $x$ & $x$ & & & & $x$ & $x$ & $x$ & & & & $x$ & $x$ & & & & & \\
\hline (Llopis, 2018) [44] & $\mathrm{x}$ & & $x$ & $x$ & & & & $\mathrm{x}$ & $x$ & $x$ & & $x$ & $x$ & $x$ & & & & & & $\mathrm{x}$ \\
\hline (Sanni, 2018) [75] & $x$ & & $x$ & $x$ & & $x$ & & & $x$ & $x$ & & & & & & $x$ & & $x$ & & $x$ \\
\hline (Cai \& Li, 2018) [46] & $\mathrm{x}$ & & $x$ & $\mathrm{x}$ & $\mathrm{x}$ & $\mathrm{x}$ & $\mathrm{x}$ & & & & $\mathrm{x}$ & $\mathrm{X}$ & $x$ & $\mathrm{x}$ & $x$ & $\mathrm{x}$ & $\mathrm{x}$ & & & \\
\hline (Orji \& Liu, 2020) [41] & $x$ & $x$ & $x$ & $x$ & $x$ & $x$ & $x$ & & & & & & & & & $\mathrm{x}$ & & & & \\
\hline This work & $x$ & $x$ & $x$ & $x$ & $x$ & $x$ & $x$ & $x$ & $x$ & $x$ & $x$ & $x$ & $x$ & $x$ & $x$ & $x$ & $x$ & $x$ & $x$ & $x$ \\
\hline
\end{tabular}




\subsubsection{Industrial Cluster Capacity}

The behavior of businesses varies depending on features such as their size, origin, type of business, and technological capabilities; it also varies depending on government support and the region's policies that condition access to human, financial, material, and technological resources. The technological capabilities of businesses to carry out innovations are directly related to absorption capacity, for which the investments made by clusters for research and development do not depreciate with time; rather, the acquired knowledge drives other innovations due to the specialized and transformation knowledge generated [76].

Eco-innovative activity is considered a complex process for businesses, since there may be financial barriers and very high technology-investment costs with considerable associated risk. Access to this kind of financing is not easy for businesses, as a strong research team at the production line is required in addition to the necessary financial resources [61,77]. Businesses must invest in formal structures in which R\&D personnel focus on new forms of production and creation of clean technologies to empower innovation processes and increase the life cycle of technology and markets [78].

Furthermore, eco-innovation processes are the creation of the management of the environmental knowledge of the network, and businesses with high capacity for technological and organizational eco-innovation can transfer this knowledge to the cluster's network. As "innovation generates innovation" is an established fact, it is highly probable that businesses that have carried out innovation activities will generate further innovations in their processes, with a better exercise of good practices within the agents making up the cluster $[12,16,53]$.

Another variable for analysis is absorption capacity (ACAP), which coincides with development based on resources and an approach set on organizational knowledge [22]. ACAP is the ability of a business to identify, assimilate, transform, and exploit external knowledge, including evaluating and employing knowledge currently related to technological or internal scientific development. The knowledge absorption exercise may have certain barriers such as a lack of qualified staff and quality machinery or equipment, a failure to establish relations or cooperation with public research institutions, and a lack of capacity to acquire external knowledge $[79,80]$.

\subsubsection{Demand Factors in Eco-Innovation}

Pressure of demand is driven by consumers' awareness and, although consumers are attracted by ecological products, they are not willing, in most cases, to pay the price of caring for the environment as it is much higher than the traditional alternative [13]. The government plays an important role in promoting more ecological and responsible awareness as well as the use of eco-innovative products, and several authors have analyzed how government subsidies and incentives affect client's motivation [81,82]. Research has been conducted on demand factors in several countries, such as Canada, France, Germany, Italy, Japan, Spain, the United Kingdom, and the United States, and it established that people may be willing to pay up to $5 \%-10 \%$ more for a product with an ecological component [83].

\subsubsection{Level of Cooperation between the Clusters' Actors}

Cooperation may be defined as the level of synergy between two or more businesses, which enables them to work jointly towards a specific objective, thus improving efficiency and market competitiveness. A fundamental aspect of the geographical cluster is the presence of high rates of cooperation and, at the same time, more intense competition between the businesses operating in it $[5,79,84]$. Additionally, Porter [5] states that cooperation favors innovation and improves clusters' overall performance, which extends vertically to the productive chain, channels, and consumers. It also extends horizontally by including businesses and industries from technology and other related sectors. Many clusters also include government institutions such as universities, research centers, and suppliers. 
In this sense, several authors have contributed a diversity of analytical concepts wherein they claim that cooperation with other businesses may be a way to share resources (see Table 2).

Table 2. Benefits of business cooperation. Compiled by author.

\begin{tabular}{cc}
\hline Contribution & Authors \\
\hline Sharing Fixed Costs & Gans \& Stern, 2003 [82] \\
Achieving Economies of Scale in R\&D & Bougrain \& Haudeville, 2002 [53] \\
Reducing Research Time & Bossink, 2002 [51] \\
Sharing Risks & Zahra \& Filatotchev, 2004 [85] \\
Accessing New Markets & Bayona, Garcia-Marco, \& Huerta, 2001 [52] \\
\hline
\end{tabular}

The cooperation between businesses and their close relationships with knowledge institutions, such as universities and research centers, are fundamental generators of eco-innovation [11]. A study carried out in Romagna (Italy) shows that cooperation with universities and suppliers is the main driver of eco-innovation [15]. This is because it is essential for eco-innovative activities to take the input of driving technological factors such as the formal knowledge factors: Universities, high schools, scientific articles, and informal knowledge factors involving suppliers, clients, and competitors.

A Latin-American cluster analysis [77] highlights the poor cooperation between the clusters' actors to perform joint actions, from businesses of the same type and from businesses or institutions that promote competitiveness. This study confirms that since clusters in developing countries have fewer capabilities, they form strategic alliances with foreign services and technologies. Additionally, businesses with advanced and mature capabilities are envious of the information and processes they possess, although they are members of the same cluster. This indicates scarce cooperation. In the same manner, government policies are not in accordance with the search for competitiveness; the cluster's needs and government policies are not aligned. Furthermore, the development of a high level of cooperation between members of a cluster leads to the development of technologies, research-derived marketing, creation of new areas for demand, and increased capacity as the system becomes adaptive to the changes in the external economy. The cluster's high level of growth and innovation results in the cluster's success [11,52].

\subsubsection{Competitive Pressure}

Today, the acceleration of technological change, market globalization, and increased competition pressures businesses into seeking to differentiate their products or services to survive in the market [19,48].

According to Becker and Dietz [80], the innovative performance of businesses depends to a large extent on market requirements, the level of technology, and the degree to which industry knowledge is updated. The greater the changes, the greater the competitive pressure, pushing businesses to increase the quality, reliability, and variety of their products and, in turn, leading to new requirements, production processes, and more aggressive innovation.

Competitive pressure is directly related to an organization's ability to create new knowledge; this is materialized by the participation of universities and research centers, as well as synergy with industrial clusters. Personnel training and level of education are necessary inputs to achieve competencies allied to new knowledge, reflecting the creation of technological improvements, patents, and disclosure of technical knowledge in scientific articles.

Another important aspect is that it drives market share through the implementation of environmental concepts and enables a change to a more ecological image. This is because as long as the pressure to seek international markets exists, the option of creating eco-innovation as a strategy to cover those markets also exists [69]. 
When businesses are economically and environmentally sustainable, they can easily redirect the existing segmentation and welcome a range of new solutions and pioneering market leading products $[63,69]$. Although competitive pressure can be considered the cause for stress within businesses, it is also a form of radical innovation that can generate high productivity rates and enable progress in the face of an increasingly changing and demanding market [1].

\subsubsection{Environmental Policies and Regulations and Their Effect on Eco-Innovative Activities}

Policies supporting eco-innovative activities are highlighted as specific determinants of eco-innovation. As they are either internal company policies (environmental management systems) or government policies, eco-innovations respond to regulatory stimuli in the form of demand (existing and expected environmental regulation) and tools for driving supply (access to subsidies) such as preferential subsidies for eco-innovation or tax policies $[17,21,27,32]$. Therefore, to initiate eco-innovative activities, large-scale changes are needed, from the creation of effective economic incentives for organizations to a change in the governments' production matrix and support of national and international policies to gain access to new markets [14].

Due to their organizational structure, clusters operate like an economic policy and develop policies that promote government actions for industry development [17,22]; the government's commitment in underdeveloped countries is important for the creation of clusters, which mostly emerge not as a spontaneous activity, but as a planned initiative. According to Bilal et al. [68], clusters enable higher levels of productivity and innovation. In a study on Italian clusters, it was found that the development of clusters varies depending on eco-innovation strategies, the number of environmental certifications (ISO 14001 and EMAS), business subsidies. and the use of new technologies to reduce pollution or resource consumption in productive processes [69,78].

\subsubsection{Economic Effects of Eco-Innovative Behavior}

The economic effects are related to savings in costs due to eco-innovative activities and is important because of its contribution to double externality, in other words, investments in economic activities that impact society without any payment or retribution from their part. The economic effects also improve resource efficiency and product quality since cost saving in businesses is the basis of further development of ecological and general innovations. Eco-innovative behavior is useful for driving the environmental performance of a business and indirectly improving its economic performance $[35,37]$. It is important to analyze how resource efficiency increases the productivity of materials in accordance with European Union indicators [14]. However, many approaches are considered at the time of its assessment $[1,25]$. One way is to analyze the income from eco-innovative services or products, the reduction of environmental costs, and the improvements to society from investment in sustainable products.

\subsubsection{Eco-Innovative Effect}

The result of eco-innovative activities is evidenced by the presence of cleaner technologies, a reduction of pollution levels, the introduction of a circular economy, and more efficient manufacturing processes and reuse of materials, which are also the variables of study proposed for this factor.

Businesses compete by taking two fundamental aspects into account: Price and differentiation. The former is related to cost reduction, either by the manufacture of products or rendering of services. Cost reduction may be achieved through energy-saving strategies or energy-efficient strategies as well as by reducing costs of raw material or the logistics process. Differentiation is the ability of businesses to include functional, ergonomic, and any other improvements that add to the value chain in their processes. By taking these aspects into account, the result of eco-innovative activities will be a product or service with a price adjusted to the competition or is better than that of competitors, and a product or service image that values sustainability. 
According to Mebratu [86], as eco-innovation impacts the life cycle and value chain, it directly affects what is expected from suppliers and distributors, creating a public image of "sustainable competitiveness". Sustainability also generates income; concern for the environment can be allayed by being loyal to brands that contribute to the environment and health and well-being of people.

Countries' capacity to innovate largely depends on businesses having competent business lines and the agility to introduce new technologies. According to Horbarch [81], patents are an indicator of the degree of implementation of innovation activities. Switzerland currently heads the Global Innovation Index for patents and publications in specialized journals; notable positions are held by the Netherlands, Sweden, the United Kingdom, Singapore, the United States, Germany, and Ireland [87]. When referring to clean technologies, such as those that do not leave a pollution footprint or, at least, practically eliminate their footprint, Switzerland creates the highest level of clean technologies worldwide.

According to the report on European clean technologies [88], Switzerland is Europe's most advanced country in the cleantech field. Notably, since 2010, the Swiss government has been playing an important part in enabling businesses to reduce their electric power consumption by using clean technologies. Similarly, it has driven the creation of businesses (SMEs) based on energy-efficient solutions. This proves the importance of the intervention of policies towards swift development and worldwide disclosure of these types of innovations [17].

Among the effects of eco-innovation, a circular economy has a catalytic effect on the value of products, resources, and supplies, maintaining their stability in the market as long as possible and reducing waste. The favorable results of a circular economy arise from the creation of strategies to reduce environmental impact through the substitution of materials, strategies to increase the number of services offered by products, and policies to extend product life as long as possible $[54,57,66]$. A circular economy implies the extraction, transformation, distribution, use, and recovery of products that improve environmental management processes in businesses. According to Mebratu [86], three sustainable dimensions, namely, economic, social, and environmental, have been the subjects of several studies to push economic sustainability forward. These are the basic dimensions to apply a circular economy and are the driving forces behind the creation of jobs, for example, in the resource sector, based on waste recycling and the conversion of resources into raw materials.

Taking the aforementioned into account, eco-innovative effects on an organizational level represent improved business awareness and initiative from executives to integrate environmental management as a strategy to improve competitiveness and obtain remarkable benefits such as cost reduction, new sources of income (sale of waste), support to the value chains of other businesses, improved quality of products and processes, and the portrayal of a higher commitment to the environment, which, consequently, helps attract more new clients and retain existing ones.

\subsubsection{Access to New Markets due to Eco-Innovative Behavior}

As pioneers in consumables from natural resources for their daily operations, businesses have the responsibility to create solutions according to the issues faced by the environment; the search for new means of production, product improvements, organizational capabilities, and distribution strategies are the challenges faced by industries through eco-innovative activities, specifically in sectors affected by the exploitation of the environment. Thus, multinational corporations and medium and small businesses, independent of their size, are becoming increasingly aware of their role in making businesses environment-friendly, and of how this improves competitiveness and is essential to protect the environment and reach new markets [82].

To gain access to new markets, it is not enough to reduce operational costs; it is also important to design socially solid, environment-friendly, and affordable products [83]. Access to new markets is related to eco-innovation in products and marketing strategies that drive product sustainability with a high added value. In effect, eco-innovation must incorporate the market either by gearing towards new business segments or by increased competitiveness, for which environmental improvements are essential [81]. 


\subsubsection{Level of Industrial Cluster Development}

When understanding the origin of the cluster creation, we must take into account that many are the results of incidental external economies and are spontaneously generated where there is a formation emerging from economic activity without the initial intention of formally creating a cluster [79]. Developed clusters are born naturally from this manner of cluster creation and are defined by their spontaneous cooperation, which are unplanned clusters emerging from a link and joined together to promote competitiveness. They create a sociocultural structure with the commitment and identity that make up the cluster. Literature states that clusters created in this manner are largely successful [77].

Notably, the cluster theory, with the new economic geography-regional agglomeration-drives surging concentrations [10] and the competitive advantage that rises from spontaneous external economies [8]. According to Porter [5], clusters are systems created spontaneously and must be studied as networks organizing themselves due to the need to adapt to and survive changing environments.

A contrasting concept is a cluster initiative (created or planned cluster) or cluster association, which has a formalized structure and a work team tasked with supporting and promoting relationships between the actors on a greater level $[34,46]$. These clusters rely on effort in order to materialize their goals and are configured with a premeditation of the environment through cooperation between actors. As per [47], it is a participative organization since policy deployment is much more complex, and its growth may take longer than expected as it is managed by the public sector on many occasions.

\section{Conclusions}

Business competitiveness is impacted by internal and external factors that must be adjusted to global markets' needs. A strategy to access these markets is the development of products and processes based on eco-innovation. This document contributes to the literature on eco-innovation in clusters through a conceptual model composed of several factors serving as guide to analyze the factors that drive eco-innovation, thereby becoming a framework of reference for future studies on this subject. In most of the studies reviewed, cooperation between the cluster's actors, ACAP, and internal capabilities of businesses are studied in a very general manner [22,86].

After performing the systematic review of the literature, the most relevant authors proposing indicators and variables to study eco-innovation in a study sector and in industrial clusters were grouped in Table 1. It also indicates which are the factors that are most often mentioned in the literature, where aspects relevant to the success of the clusters are highlighted, such as the level of cooperation between the authors, presence of support institutions, knowledge management through research, etc., and aspects relevant to eco-innovation. We proposed to consider these factors, integrate them and complement them in a model that can help identify which are the key factors that impact the transformation of a cluster with an eco-innovative component. The proposed internal factors are: The capacity of the cluster, which analyses the capacity of human resources and technology and knowledge transfer available to companies belonging to the cluster in order to deal with eco-innovation [81]; the demand factor, which analyses the pressure on consumers to use greener products and how governments and incentive policies affect collective awareness of the market; cooperation, which establishes the synergy between the actors in the cluster, while the competitive pressure factor encourages companies to create a differentiation in their products or services that allow them to survive in the market; environmental policies and regulations in clusters, which operate through actions that promote government incentives for the development of industries, as well as regulations for their good development; and the level of development of the cluster, which is related to understanding the origin of the cluster. In this case, the spontaneous or natural clusters and cluster initiatives will be studied.

The proposed external factors are: The economic effect due to eco-innovative behavior, which is related to cost savings for eco-innovative activities and is very significant due to its contribution to double externality; the eco-innovative effect, which is the result of good environmental practices, from which a result is the presence of cleaner technologies, reduction of pollution levels, introduction of a circular economy, more efficient manufacturing processes, and the reuse of materials; and access to 
new markets, which is related to eco-innovation in products and marketing strategies that promote sustainability in products, with high added value.

Considering the above, the validation of this proposed model and its subsequent application as a tool for analysis and improvement of the level and innovative eco-capacity in industrial clusters will have implications both at the strategic level in business decision-making and at the operational level in the field of cost reduction or use of resources. The survey will be deployed among the selected companies belonging to a cluster, creating a unique database that will be analyzed using fuzzy sets QCA methodology in order to extract conclusions with both managerial and policy implications that will help companies within the cluster better orientate their eco-innovative orientation.

By focusing on industrial clusters, the model gives considerable relevance to the level of cooperation, an indicator of the degree of synergy between the cluster's actors, and proposes a level of cooperation between universities, distributors, suppliers, competitors, and clients of the cluster.

Literature highlights the steps taken by governments in creating sustainable systems within organizations to support the reduction of the carbon footprint and ensure improvement of materials, clean technologies, and to develop functional organizations with high standards of quality, focused on improving their effect on the environment through their practices. The role of consumers is also essential in changing mindsets, as consumer habits determine the value of products or services and make organizations design a more ecological image and incorporate green marketing and eco-labelling. Therefore, it is considered essential to include client demand in the model as an input factor enabling change within business activities. An under-researched aspect, taken into account in this model, is the level of cluster development; the cluster's nature impacts the decision-making and competitiveness of its businesses. The size and the sector to which the cluster belongs are also considered in this model, as there is a direct relation between business size and its ability to create innovation and access new markets [83]. Of the external factors, we highlight the circular economy, as it is a relatively new concept in literature and businesses need to be more aware of its importance as a strategy in reducing the consumption and wastage of raw materials, energy, and water. There are multiple implications of this study. It can serve as a guide for managers to understand the key variables on which to act to properly guide the strategies of companies, as well as public and private organizations, to adapt policies, promote rapid adaptation to new needs that society raises, and promote sustainable innovations in industrial clusters.

This article addresses a deep understanding of the eco-innovation process and is beneficial to politicians, indicator developers, and buyers who need to learn which determinants would better prepare them for strategic implementation. It would help strengthen cluster networks to facilitate the environment for new participants.

Finally, the proposed model provides an interesting instrument to create government policies that aim to promote cluster eco-innovations, aligned with the reduction of pollution and the creation of strong innovation platforms on which companies can obtain support to strengthen their organizational capacities.

The study presents some limitations that are also linked with future lines of research. The theoretical study highlighted the main constructs affecting the eco-innovative orientation of firms belonging to industrial clusters. The proposed model will be completed, firstly, with a quantitative analysis. The Qualitative Comparative Analysis Using Fuzzy Sets (FsQCA) will be used to validate the model results. Then, in depth cases will be deployed to confirm and enrich the theoretical model.

Direct implications for companies and policy makers arise from the model that puts together the seminal references regarding eco-innovation, competitive enhancement, and clusters theory. This triple strategic focus is a new approach to managerial decision's making process that usually envisions each of them separately.

Author Contributions: Conceptualization, N.M.-C. and M.S.-O.; data curation, N.M.-C. and A.P.-S.; formal analysis, N.M.-C.; resources, D.O.-G.; supervision, M.S.-O.; validation, N.M.-C. and D.O.-G.; writing-review \& editing, N.M.-C., M.S.-O., and A.P.-S. All authors have read and agreed to the published version of the manuscript. 
Funding: This research received no external funding.

Acknowledgments: The authors acknowledge Universidad de la Costa, Universitat Politecnica de Valencia for its support and for hosting prof. Mercado-Caruso as a visiting scholar, and Universidad Simón Bolivar for their support.

Conflicts of Interest: The authors declare no conflict of interest.

\section{Appendix A. Questionnaire}

The objective of the survey is to analyze eco-innovative activities in companies belonging to industrial clusters. Eco-innovation is the introduction of a new product or process that adds value to a business or a client by reducing the environmental impact. An innovation with environmental benefits is a new or significantly improved product, process, organization method, or marketing method that creates benefits compared to other alternatives.

A. COMPANY INFORMATION

1. Indicate the Total number of employees of the Organization. (Please tick the correct box)

(1) Less than 10 employees.

(2) Between 11 and 50 employees.

(3) Between 51 and 250 employees.

(4) More than 250 employees

2. Please indicate the sector to which your company belongs (Please tick the correct box)

\begin{tabular}{|c|c|}
\hline 1. Agriculture & 7. Transportation \\
\hline 2. Mining and energy & 8. Agriculture \\
\hline 3. Construction & 9. Financial \\
\hline 4. Manufacturing & 10. Communications \\
\hline 5. Transportation & 11. Metalworking \\
\hline 6. Trade & 12. Social Services \\
\hline
\end{tabular}

3. Year of the company's foundation

4. City where the company is located

5. Type of company (Please tick the correct box)

\begin{tabular}{|l|l|}
\hline 1. Public & \\
\hline 2. Private without foreign participation & \\
\hline 3. Private with participation $<10 \%$ of foreign capital & \\
\hline 4. Private with participation $>10 \%$ and $<50 \%$ of foreign capital & \\
\hline 5. Private with participation $>50 \%$ of foreign capital. & \\
\hline 6. Research association and other research institutions & \\
\hline
\end{tabular}

6. Is your company located in a Science or Technology Park? Yes, Park Name: No

7. In which geographic markets did your enterprise sell goods and/or services?

\begin{tabular}{|l|l|}
\hline 1. Local / regional market & \\
\hline 2. National & \\
\hline 3. Mercosur / Latin America & \\
\hline 4. All other countries & \\
\hline
\end{tabular}

8. Position in the Company

The following topics describe the driving factors behind your enterprise's implementation of eco-innovation and its impact on the performance.

Please indicate to what extent you agree or disagree with the following statements (1-strongly disagree to 7-strongly agree) 


\begin{tabular}{|c|c|c|c|c|c|c|c|}
\hline Cluster Capacity & 1 & 2 & 3 & 4 & 5 & 6 & 7 \\
\hline ar company is appropriate. & 1 & 2 & 3 & 4 & 5 & 6 & 7 \\
\hline $\begin{array}{l}\text { It is practical for your company to use consulting services focused on planning, } \\
\text { evaluation and training on environmental issues. }\end{array}$ & 1 & 2 & 3 & 4 & 5 & 6 & 7 \\
\hline Your company has been successful regarding to eco-innovation. & 1 & 2 & 3 & 4 & 5 & 6 & 7 \\
\hline Your company has the necessary resources for the design of green/sustainable products. & 1 & 2 & 3 & 4 & 5 & 6 & 7 \\
\hline $\begin{array}{l}\text { Your company's research and development team has very solid and mature design } \\
\text { capabilities. }\end{array}$ & 1 & 2 & 3 & 4 & 5 & 6 & 7 \\
\hline $\begin{array}{l}\text { Your company provides incentives or bonuses to people who have made contributions } \\
\text { to energy conservation and emission reduction. }\end{array}$ & 1 & 2 & 3 & 4 & 5 & 6 & 7 \\
\hline $\begin{array}{l}\text { The acquisition of external knowledge is positively related to the responsiveness of the } \\
\text { organization. }\end{array}$ & 1 & 2 & 3 & 4 & 5 & 6 & 7 \\
\hline $\begin{array}{l}\text { The assimilation of external knowledge is positively related to the responsiveness of } \\
\text { the organization. }\end{array}$ & 1 & 2 & 3 & 4 & 5 & 6 & 7 \\
\hline
\end{tabular}

\begin{tabular}{llllllll}
\hline Demand Factor & \multicolumn{7}{c}{ Degree of importance } \\
\hline The environment is a critical issue for your important clients. & 1 & 2 & 3 & 4 & 5 & 6 & 7 \\
The environment is a critical issue for your important suppliers. & 1 & 2 & 3 & 4 & 5 & 6 & 7 \\
Your important clients often pose environmental problems. & 1 & 2 & 3 & 4 & 5 & 6 & 7 \\
Customer demands motivate your company in the environmental efforts. & 1 & 2 & 3 & 4 & 5 & 6 & 7 \\
Your clients have clear environmental demands. & 1 & 2 & 3 & 4 & 5 & 6 & 7 \\
\hline
\end{tabular}

Level cooperation Please indicate to which degree there is relationship among the parties within the cluster your company belongs to.

Degree of importance

Your company cooperates with other companies belonging to the same holding.

Your company cooperates with local, regional, or national governmental agencies or policy makers.

Your company cooperates with other companies within the cluster.

$\begin{array}{lllllll}1 & 2 & 3 & 4 & 5 & 6 & 7\end{array}$

Your company cooperates with public or private clients.

Your company cooperates with universities or research agencies.

Your company cooperates with suppliers, materials, component, or software providers.

\begin{tabular}{|c|c|c|c|c|c|c|c|}
\hline $\begin{array}{l}\text { Competitive pressure Please indicate the level of agreement with the following } \\
\text { statements }\end{array}$ & & & & & & & \\
\hline Your company's environmental image is better compared to the competitors. & 1 & 2 & 3 & 4 & 5 & 6 & 7 \\
\hline Your company increases its market share through green concepts. & 1 & 2 & 3 & 4 & 5 & 6 & 7 \\
\hline $\begin{array}{l}\text { Your company improves its competitive advantage of the company over the } \\
\text { competition through ecological concepts. }\end{array}$ & 1 & 2 & 3 & 4 & 5 & 6 & 7 \\
\hline
\end{tabular}

\begin{tabular}{|c|c|c|c|c|c|c|c|}
\hline \multicolumn{8}{|l|}{$\begin{array}{l}\text { Regulatory policies } \\
\text { (1)Please indicate the level of agreement with the following statements }\end{array}$} \\
\hline $\begin{array}{l}\text { Your company participates in voluntary actions or initiatives for environmental good } \\
\text { practice within your sector. }\end{array}$ & 1 & 2 & 3 & 4 & 5 & 6 & 7 \\
\hline Your company considers environmental auditing as an internal management standard. & 1 & 2 & 3 & 4 & 5 & 6 & 7 \\
\hline $\begin{array}{l}\text { Your company works under the principles of ISO } 14000 . \\
\text { (2) How important were the following factors in driving your enterprise's decisions to } \\
\text { introduce innovations with environmental benefits? } \\
\text { Existing environmental regulations } \\
\text { Existing environmental taxes, charges, or fees }\end{array}$ & 1 & 2 & 3 & 4 & 5 & 6 & 7 \\
\hline $\begin{array}{l}\text { Environmental regulations or taxes expected in the future } \\
\text { Government grants, subsidies, or other financial incentives for environmental } \\
\text { innovations }\end{array}$ & 1 & 2 & 3 & 4 & 5 & 6 & 7 \\
\hline Current or expected market demand for environmental innovations & & & & & & & \\
\hline $\begin{array}{l}\text { Government grants, subsidies, or other financial incentives for environmental } \\
\text { innovations }\end{array}$ & & & & & & & \\
\hline
\end{tabular}

Eco-innovative effects. Please indicate how important are the introduction of a product (good or service), process, organizational, or marketing innovation with any of Degree of importance the following environmental benefits for your company.

Low energy consumption such as water, electricity, gas, and gasoline during production/use/disposal

Recycle, reuse, and remanufacture material

Using cleaner technologies to generate savings and prevent pollution (such as energy, water, and waste)

$\begin{array}{lllllll}1 & 2 & 3 & 4 & 5 & 6 & 7 \\ 1 & 2 & 3 & 4 & 5 & 6 & 7 \\ 1 & 2 & 3 & 4 & 5 & 6 & 7\end{array}$




\begin{tabular}{llllllll}
\hline Generation of patents by substitution of materials for other less polluting or dangerous & 1 & 2 & 3 & 4 & 5 & 6 & 7 \\
Reduction of materials or water per unit produced & 1 & 2 & 3 & 4 & 5 & 6 & 7 \\
Implementation of circular economy & 1 & 2 & 3 & 4 & 5 & 6 & 7 \\
Reduction of energy or $\mathrm{CO}_{2}$ & 1 & 2 & 3 & 4 & 5 & 6 & 7 \\
Extended product life through more durable products & 1 & 2 & 3 & 4 & 5 & 6 & 7 \\
\hline
\end{tabular}

Access to new markets During the past two years, how important were the following factors in driving your company's decisions to introduce innovations with Degree of importance environmental benefits?

\begin{tabular}{llllllll}
\hline Export of products derived from eco-innovation & 1 & 2 & 3 & 4 & 5 & 6 & 7 \\
Ability to pay existing environmental taxes, fees, or duties & 1 & 2 & 3 & 4 & 5 & 6 & 7 \\
Environmental regulations or taxes foreseen in the future & 1 & 2 & 3 & 4 & 5 & 6 & 7 \\
Government support through financial incentives for exporting companies with & 1 & 2 & 3 & 4 & 5 & 6 & 7 \\
innovative components & 1 & 2 & 3 & 4 & 5 & 6 & 7 \\
Significant current or expected market demand for environmental innovations & 1 & 2 & 3 & 4 & 5 & 6 & 7 \\
Access to new markets as a strategy to improve the company's reputation & 1 & 2 & 3 & 4 & 5 & 6 & 7 \\
\hline Compliance with public procurement requirements to access international projects & & 1
\end{tabular}

Economic effects During the past three years, how important were the following economic effects derived from eco-innovations in your company?

\begin{tabular}{llllllll}
\hline Cost reduction of energy, water, or materials & 1 & 2 & 3 & 4 & 5 & 6 & 7 \\
Increase of sales for products with eco-labelling & 1 & 2 & 3 & 4 & 5 & 6 & 7 \\
Investments in eco-innovative aspects & 1 & 2 & 3 & 4 & 5 & 6 & 7 \\
\hline
\end{tabular}

\section{References}

1. Esty, D.C.; Winston, A. Green to Gold: How Smart Companies Use Environmental Strategy to Innovate, Create Value, and Build Competitive Advantage; John Wiley \& Sons: Hoboken, NJ, USA, 2009.

2. OECD. Eco-Innovation in Industry: Enabling Green Growth; OECD Publishing: Paris, France, 2010.

3. Peiro-Signes, A.; Segarra-Ona, M.; Meseguer-Santamaría, L.; Mondéjar-Jiménez, J. Can eco-innovative orientation be explained? An attempt to understand uncovered patterns. Environ. Eng. Manag. J. 2013, 12, 1933-1939.

4. Buhl, A.; Blazejewski, S.; Dittmer, F. The more, the merrier: Why and how employee-driven eco-innovation enhances environmental and competitive advantage. Sustainability 2016, 8, 946. [CrossRef]

5. Porter, M.E. Clusters and the New Economics of Competition; Harvard Business Review: Boston, MA, USA, 1998; Volume 76, pp. 77-90.

6. Hervás-Oliver, J.L.; Albors-Garrigós, J. Do clusters capabilities matter? An empirical application of the resource-based view in clusters. Entrepreneurship Reg. Dev. 2007, 19, 113-136. [CrossRef]

7. Bell, G.G. Clusters, networks, and firm innovativeness. Strateg. Manag. J. 2005, 26, 287-295. [CrossRef]

8. Hervas-Oliver, J.L.; Sempere-Ripoll, F.; Rojas Alvarado, R.; Estelles-Miguel, S. Agglomerations and firm performance: Who benefits and how much? Reg. Stud. 2018, 52, 338-349. [CrossRef]

9. Hervas-Oliver, J.L.; Gonzalez, G.; Caja, P.; Sempere-Ripoll, F. Clusters and industrial districts: Where is the literature going? Identifying emerging sub-fields of research. Eur. Plan. Stud. 2015, 23, 1827-1872. [CrossRef]

10. Cruz, S.C.S.; Teixeira, A.A.C. The Evolution of the Cluster Literature: Shedding Light on the Regional Studies-Regional Science Debate. Reg. Stud. 2010, 44, 1263-1288. [CrossRef]

11. Arita, T.; Fujita, M.; Kameyama, Y. Effect of regional cooperation among small and medium-sized firms on thier growth in Japanese industrial clusters. Rev. Urban Reg. Dev. Stud. 2006, 18, 209-228. [CrossRef]

12. López Jiménez, J.; Martínez Gutiérrez, B.; Hernández Malpica, P.E.; Rodríguez Barquero, R. Determinants of performance cluster: Case applied to furniture industry in Barranquilla, Colombia. Tec Empresarial 2016, 10, 29-38. [CrossRef]

13. Porter, M.E.; Van der Linde, C. Toward a new conception of the environment-competitiveness relationship. J. Econ. Perspect. 1995, 9, 97-118. [CrossRef]

14. Comisión Europea. Ecoinnovación la clave de la competitividad de Europa en el futuro; European Unión: Brussels, Belgium, 2011.

15. Daddi, T.; De Giacomo, M.R. Cluster approach and eco-innovation in four industrial clusters of Tuscany region (Italy). Environ. Econ. 2012, 3, 26-34.

16. Sara, T.; Tiberio, D. The link between environmental and economic performance: Evidence from some eco-innovative industrial clusters. Int. J. Environ. Sustain. Dev. 2013, 12, 124. 
17. Kemp, R.; Pontoglio, S. The innovation effects of environmental policy instruments-A typical case of the blind men and the elephant? Ecol. Econ. 2011, 72, 28-36. [CrossRef]

18. Segarra-Ona, M.; Peiró-Signes, Á.; Mondéjar-Jiménez, J.; Vargas-Vargas, M. Service vs. manufacturing: How to address more effectively eco-innovation public policies by disentangling the different characteristics of industries. Innovation 2014, 27, 134-151. [CrossRef]

19. Peiró-Signes, Á.; Segarra-Oña, M.; Miret-Pastor, L.; Verma, R. Eco-innovation attitude and industry's technological level-an important key for promoting efficient vertical policies. Environ. Eng. Manag. J. 2011, 10, 1893-1901. [CrossRef]

20. Kemp, R. Eco-Innovation and Transitions. Econ. Policy Energy Environ. 2009, 52, 103-124.

21. Machiba, T. Eco-innovation for enabling resource efficiency and green growth: Development of an analytical framework and preliminary analysis of industry and policy practices. Int. Econ. Econ. Pol. 2010, 7, 357-370. [CrossRef]

22. Tessitore, S.; Daddi, T.; Iraldo, F. Eco-innovation and economic performance in industrial clusters: Evidence from Italy. World Acad. Sci. Eng. Technol. 2010, 42, 1487-1493.

23. Delgado, M.; Porter, M.E.; Stern, S. Defining clusters of related industries. J. Econ. Geogr. 2016, 16, 1-38. [CrossRef]

24. Fernando, Y.; Jabbour, C.J.C.; Wah, W.-X. Pursuing green growth in technology firms through the connections between environmental innovation and sustainable business performance: Does service capability matter? Resour. Conserv. Recycl. 2019, 141, 8-20. [CrossRef]

25. Kemp, R.; Horbach, J. Measurement of Competitiveness of Eco-Innovation. In Measuring Eco-innovation Project (MEI); Univesity of Maastricht: Maastricht, The Netherlands, 2007.

26. Kemp, R.; Pearson, P. Final report MEI project about measuring eco-innovation. UM Merit Maastricht 2007, 32, 121-124.

27. Kanerva, M.; Arundel, A.; Kemp, R. Environmental Innovation: Using Qualitative Models to Identify Indicators for Policy; UNU-MERIT: Maastricht, The Netherlands, 2009; pp. 1-54.

28. Stosic, B.; Milutinovic, R.; Zakic, N.; Zivkovic, N. Selected indicators for evaluation of eco-innovation projects. Innovation 2016, 29, 177-191. [CrossRef]

29. Miret Pastor, L.G.; Segarra Oña, M.; Peiró Signes, Á. Cómo medimos la Ecoinnovación? Análisis de indicadores en el Sector Turístico. Tec Empresarial 2011, 5, 15-25.

30. Bossle, M.B.; Dutra De Barcellos, M.; Vieira, L.M.; Sauvée, L. The drivers for adoption of eco-innovation. J. Clean. Prod. 2016, 113, 861-872. [CrossRef]

31. Hojnik, J.; Ruzzier, M. What drives eco-innovation? A review of an emerging literature. Environ. Innov. Soc. Transit. 2016, 19, 31-41. [CrossRef]

32. Kesidou, E.; Demirel, P. On the drivers of eco-innovations: Empirical evidence from the UK. Res. Policy 2012, 41, 862-870. [CrossRef]

33. Pellegrini, C.; Annunziata, E.; Rizzi, F.; Frey, M. The role of networks and sustainable intrapreneurship as interactive drivers catalyzing the adoption of sustainable innovation. Corp. Soc. Responsib. Environ. Manag. 2019, 26, 1026-1048. [CrossRef]

34. Rodríguez-García, M.; Guijarro-García, M.; Carrilero-Castillo, A. An overview of ecopreneurship, eco-innovation, and the ecological sector. Sustainability 2019, 11, 2909. [CrossRef]

35. Scarpellini, S.; Valero-Gil, J.; Rivera-Torres, P.; Garces-Ayerbe, C. Analysis of the generation of economic results in the different phases of the pro-environmental change process. J. Clean. Prod. 2017, 168, 1473-1481. [CrossRef]

36. Ociepa-Kubicka, A.; Pachura, P. Eco-innovations in the functioning of companies. Environ. Res. 2017, 156, 284-290. [CrossRef]

37. Scarpellini, S.; Valero-Gil, J.; Portillo-Tarragona, P. The "economic-finance interface" for eco-innovation projects. Int. J. Proj. Manag. 2016, 34, 1012-1025. [CrossRef]

38. Hojnik, J.; Ruzzier, M. The driving forces of process eco-innovation and its impact on performance: Insights from Slovenia. J. Clean. Prod. 2016, 133, 812-825. [CrossRef]

39. Segarra-Oña, M.; Peiró-Signes, A.; Albors-Garrigós, J.; Miguel-Molina, B. Testing the Social Innovation Construct: An Empirical Approach to Align Socially Oriented Objectives, Stakeholder Engagement, and Environmental Sustainability. Corp. Soc. Responsib. Environ. Manag. 2017, 24, 15-27. [CrossRef] 
40. Afshari, H.; Searcy, C.; Jaber, M.Y. The role of eco-innovation drivers in promoting additive manufacturing in supply chains. Int. J. Prod. Econ. 2020, 223, 107538. [CrossRef]

41. Orji, I.J.; Liu, S. A dynamic perspective on the key drivers of innovation-led lean approaches to achieve sustainability in manufacturing supply chain. Int. J. Prod. Econ. 2020, 219, 480-496. [CrossRef]

42. Arundel, A.; Kemp, R. Measuring Eco-Innovation; United Nations University: Tokyo, Japan, 2009.

43. Cheng, C.C.; Shiu, E.C. Validation of a proposed instrument for measuring eco-innovation: An implementation perspective. Technovation 2012, 32, 329-344. [CrossRef]

44. Jové-Llopis, E.; Segarra-Blasco, A. Eco-innovation strategies: A panel data analysis of Spanish manufacturing firms. Bus. Strateg. Environ. 2018, 27, 1209-1220. [CrossRef]

45. Segarra-Ona, M.; Peiro-Signes, A.; Cervello-Royo, R. A Framework to Move Forward on the Path to Eco-innovation in the Construction Industry: Implications to Improve Firms' Sustainable Orientation. Sci. Eng. Ethics 2015, 21, 1469-1484. [CrossRef]

46. Cai, W.; Li, G. The drivers of eco-innovation and its impact on performance: Evidence from China. J. Clean. Prod. 2018, 176, 110-118. [CrossRef]

47. Salas, K.; Acosta Villa, C.; Sandoval Cortes, L.; Pacheco, G.; Mercado Caruso, N. Strategic analysis of cluster of logistics services. Espacios 2016, 37, 5.

48. Lundequist, P.; Power, D. Putting Porter into practice? Practices of regional cluster building: Evidence from Sweden. Eur. Plan. Stud. 2002, 10, 685-704. [CrossRef]

49. Sáez-Martínez, F.J.; Díaz-García, C.; Gonzalez-Moreno, A. Firm technological trajectory as a driver of eco-innovation in young small and medium-sized enterprises. J. Clean. Prod. 2016, 138, 28-37. [CrossRef]

50. Rodríguez-Sánchez, J.L.; Montero-Navarro, A.; Gallego-Losada, R. The opportunity presented by technological innovation to attract valuable human resources. Sustainability 2019, 11, 5785. [CrossRef]

51. Bossink, B. The development of co-innovation strategies: Stages and interaction patterns in interfirm innovation. RD Manag. 2002, 32, 311-320. [CrossRef]

52. Bayona, C.; Garcia-Marco, T.; Huerta, E. Firms' motivations for cooperative R\&D: An empirical analysis of Spanish firms. Res. Policy 2001, 30, 1289-1307.

53. Bougrain, F.; Haudeville, B. Innovation, collaboration and SMEs internal research capacities. Res. Policy 2002, 31, 735-747. [CrossRef]

54. De Gouvea, R.; Kassicieh, S. Building an eco-innovation cluster: Water cluster in the Brazilian Amazon region. In Sustainable Policy Applications for Social Ecology and Development; IGI Global: Hershey, PA, USA, 2012; pp. 87-100.

55. Cluster Eco Construction-European Cluster Collaboration Platform. 2020. Available online: https: //www.clustercollaboration.eu/cluster-organisations/cluster-eco-construction. (accessed on 20 July 2020).

56. Peiró-Signes, Á.; Segarra-Oña, M. How past decisions affect future behavior on eco-innovation: An empirical study. Bus. Strategy Environ. 2018, 27, 1233-1244. [CrossRef]

57. Smol, M.; Kulczycka, J. Circular economy indicators in relation to eco-innovation in European regions.Clean Technol. Environ. Policy 2017, 19, 669-678. [CrossRef]

58. Cainelli, G.; D'Amato, A.; Mazzanti, M. Resource efficient eco-innovations for a circular economy: Evidence from EU firms. Res. Policy 2020, 49, 103827. [CrossRef]

59. Vence, X.; Pereira, Á. Eco-innovation and Circular Business Models as drivers for a circular economy. Contad. Y Adm. 2019, 64, 1-19. [CrossRef]

60. Pigosso, D.C.A.; Schmiegelow, A.; Andersen, M.M. Measuring the Readiness of SMEs for Eco-Innovation and Industrial Symbiosis: Development of a Screening Tool. Sustainability 2018, 10, 2861. [CrossRef]

61. Barsoumian, S.; Severin, A.; Van der Spek, T. Eco-Innovation and National Cluster Policies in Europe; Europe INNOVA, European Cluster Observatory: Brussels, Belgium, 2011.

62. De Marchi, V. Environmental innovation and R\&D cooperation: Empirical evidence from Spanish manufacturing firms. Res. Policy 2012, 41, 614-623.

63. Horbach, J. Determinants of environmental innovation-New evidence from German panel data sources. Res. Policy 2008, 37, 163-173. [CrossRef]

64. Horbach, J.; Oltra, V.; Belin, J. Determinants and specificities of eco-innovations compared to other innovations-An econometric analysis for the French and German industry based on the community innovation survey. Ind. Innov. 2013, 20, 523-543. [CrossRef] 
65. Mondéjar-Jiménez, J.; Segarra-Oña, M.; Peiró-Signes, Á.; Payá-Martínez, A.M.; Sáez-Martínez, F.J. Segmentation of the Spanish automotive industry with respect to the environmental orientation of firms: Towards an ad-hoc vertical policy to promote eco-innovation. J. Clean. Prod. 2015, 86, 238-244. [CrossRef]

66. Segarra-Onã, M.; Peiró-Signes, A.; Payá-Martínez, A. Factors influencing automobile firms' eco-innovation orientation. Eng. Manag. J. 2014, 26, 31-38. [CrossRef]

67. Diaz Lopez, F.J.; Montalvo, C. A comprehensive review of the evolving and cumulative nature of eco-innovation in the chemical industry. J. Clean. Prod. 2015, 102, 30-43. [CrossRef]

68. Diaz Lopez, F.; Bastein, T.; Tukker, A. Business Model Innovation for Resource-efficiency, Circularity and Cleaner Production: What 143 Cases Tell Us. Ecol. Econ. 2019, 155, 20-35. [CrossRef]

69. Arranz, N.; Arroyabe, C.F.; Carlos, J.; Arroyabe, F. The effect of regional factors in the development of eco -innovations in the firm. Bus. Strateg. Environ. 2019, 28, 1406-1415. [CrossRef]

70. Bilal, A.R.; Khan, A.A.; Akoorie, M.E.M. Constraints to growth: A cross country analysis of Chinese, Indian and Pakistani SMEs. Chin. Manag. Stud. 2016, 10, 365-386. [CrossRef]

71. Veugelers, R. "Which policy instruments to induce clean innovating?". Res. Policy 2012, 41, 1770-1778. [CrossRef]

72. Ghisetti, C.; Marzucchi, A. Does external knowledge affect environmental innovations? An empirical investigation of eleven European countries. Res. Policy 2014, 44, 1-36.

73. Borghesi, S.; Cainelli, G.; Mazzanti, M. Linking emission trading to environmental innovation: Evidence from the Italian manufacturing industry. Res. Policy 2015, 44, 669-683. [CrossRef]

74. Del Rio, P.; Romero-Jordan, D.; Penasco, C. Analysing firm-specific and type-specific determinants of eco-innovation. Technol. Econ. Dev. Econ. 2017, 23, 259-270. [CrossRef]

75. Sanni, M. Drivers of eco-innovation in the manufacturing sector of Nigeria. Technol. Forecast. Soc. Chang. 2018, 131, 303-314. [CrossRef]

76. Danko, L.; Bednář, P.; Matošková, J. Managers' activities within cultural and creative clusters: An essential element for cluster development in the Visegrád countries. Creat. Stud. 2017, 10, 26-42. [CrossRef]

77. Rovira, S.; Patiño, J.A.; Schaper, M. Ecoinnovación y Producción verde: Una Revisión Sobre las Políticas de América Latina y el Caribe; CEPAL: Santiago, Chile, 2017.

78. Carpinetti, L.C.R.; Galdámez, E.V.C.; Gerolamo, M.C. A measurement system for managing performance of industrial clusters: A conceptual model and research cases. Int. J. Prod. Perform. Manag. 2008, 57, 405-419. [CrossRef]

79. Dohse, D. Cluster-based technology policy-The German experience. Ind. Innov. 2007, 14, 69-94. [CrossRef]

80. Cohen, W.M.; Levinthal, D.A. Absorptive Capacity: A New Perspective on Learning and Innovation. Adm. Sci. Q. 1990, 35, 128-152. [CrossRef]

81. Doz, Y.L.; Hamel, G. Alliance Advantage: The Art of Creating Value through Partnering; Harvard Business Press: Boston, MA, USA, 1998.

82. Becker, W.; Dietz, J. R\&D cooperation and innovation activities of firms-Evidence for the German manufacturing industry. Res. Policy 2004, 33, 209-223.

83. Horbach, J.; Rammer, C.; Rennings, K. Determinants of eco-innovations by type of environmental impact-The role of regulatory push/pull, technology push and market pull. Ecol. Econ. 2012, 78, 112-122. [CrossRef]

84. Hong, Y.P.; Kim, Y.; Cin, B.C. Product-Service System and Firm Performance: The Mediating Role of Product and Process Technological Innovation. Emerg. Mark. Financ. Trade 2015, 51, 975-984. [CrossRef]

85. Zahra, S.A.; Filatotchev, I. Governance of the Entrepreneurial Threshold Firm: A Knowledge-based Perspective. J. Manag. Stud. 2004, 41, 885-897. [CrossRef]

86. Mebratu, D. Sustainability and sustainable development: Historical and conceptual review. Environ. Impact Assess. Rev. 1998, 18, 493-520. [CrossRef]

87. European Cluster Collaboration Platform (ECCP). 2020. Available online: https://www.clustercollaboration. eu/search/node/cleantechnologies (accessed on 20 July 2020).

88. Gans, J.S.; Stern, S. The product market and the market for 'ideas': Commercialization strategies for technology entrepreneurs. Res. Policy 2003, 32, 333-350. [CrossRef]

(C) 2020 by the authors. Licensee MDPI, Basel, Switzerland. This article is an open access article distributed under the terms and conditions of the Creative Commons Attribution (CC BY) license (http://creativecommons.org/licenses/by/4.0/). 